\title{
Thomas Middleton's Legal Duel: A Cognitive Approach
}

\section{by John-Wilhelm Vinje}

The close performative and linguistic aspect - together with the socio-cultural relationship and historical interpretation - between a court of law and a law-trial scene seen in a play is evident as their historical performative expression frequently seems to overlap. With socially accepted and embedded rites and roles, a dramatic legal scene can be interpreted as a critique of the way the juridical system in Early Modern London became more and more corrupt. The scenes are constructed of a range socio-cultural language that performed on a social stage. How, may one ask, does a performance of a trial scene and the use of cognitive metaphoric language influence the way Jacobean society can be interpreted? I will argue that the blending of social spaces seen in these cognitive metaphors is interpretatively multilayered and function as vivid and complex metaphors and social comments.

The plot structure found in Thomas Middleton's play The Phoenix, and the allegorical character compositions, outlines the socio-political impact in contemporary Jacobean London. I approach the textual and conceptual representation of order in society, and here specifically the legal and bureaucratic discourses, from a combined angle of cognitive metaphor theory and historicism. Cognitive structures and metaphoric architecture form some of the basis for innovative creativity, such as information processing and synthesising of simple metaphors into complex structures of allegorical stories and personifications of socio-political functions. With this type of cognitive metaphor reading a renewed understanding of how metaphoric language of the theatre and theatrical representation of Early Modern legal society function may be achieved.

For such an approach one needs also to approach how law and drama interact with the social semiotics of the linguistic and social domains and with the emergence of several new discourses. These new discourses are the development of a modern legal system, an established professionalism of politics, and of course the modern theatre stage. With these social discourses followed entirely new sets of conceptual categories of language, which again contributed - with the mutual influence these had on each other, both in terms of new social functions and the need for new discourse languages - to a reconfiguration of the social structures of power and reality. Reminiscence of the linguist Benjamin Lee Whorf, ${ }^{1}$ the cognitive linguist George Lakoff noted that "We commonly take our conceptual metaphors as defining reality" (Lakoff, 2008, 25), which in many cases can be said to describe how theatrical language and the social blending of legal and stage space contribute

$\overline{1}$ See Whorf (1959). 
strongly to the development of society. In this paper I look at how the legal language in The Phoenix is defined, appropriated and developed both in the court room and on the stage. The specific example is the Duel Scene (9, 99-277 (II.iii)). ${ }^{2}$ The reason for this selection is the Middleton's close relationship with legal matters, even as he was not an educated lawyer at the Inns of Court, he had extensive knowledge of legal practice as well as the languages of the law, partly due to a fifteen year long legal battle after the death of his father and his mother's remarriage. But partly also due to his many friends at the Inns, such as John Webster, John Ford and Sir Thomas Overbury. A second reason is his specific appropriation of these languages during what may be termed a time of juridical crisis. After the death of Queen Elizabeth I, without a proper heir to the throne, and the accession of James I, a fair few questioned James divine right of kings and James's divine and legal right to the throne, even though James himself wrote about the Divine Right of Kings in The True Law of Free Monarchies (1598), which discusses this at length. This uncertainty, with the death of several of Elizabeth's key statesmen such as Lord Burleigh and Francis Walsingham, and the conflict with the Lord Chief Justice Coke, ${ }^{3}$ gave rise to an uncertainty of juridical confidence, and prompted a new kind of juridical plays openly criticising legal and royal matters. Throughout the Stuarts this distrust grew, and reached its peak with the trial and execution of Charles I. ${ }^{4}$

The importance of the historical socio-cultural position of theatre is evident not only from the amount of study devoted to the fields of drama and the theatre, but also in the impact the comparable social speech acts independently of each other though theatricality. This impact has contributed to the formation and development of the discourses and the different verbal and non-verbal languages of society. The close link between language, theatre and law is also visible in the exchange of conceptual categories of metaphoric language. Language, everyday ritual and society were formed in a rapid pace through the overlapping of social spaces such as the political, legal and theatrical during the Early Modern era in England as a result of numerous major changes such as the Reformation and the formation of a more professional political and legal system. From the offset of Early Modern political and legal discourses, theatricality and rituals had been integrated in the representation of the spaces of society, and the development of social discourses. The mutual flow of social energy $y^{5}$ between these aspects

$2 \quad$ All quotations are from Middleton (2007).

3 See Boyer et. al. 2004

4 Because of the limited space available in this paper I am not able to venture further into this field of study. For more detailed accounts see e.g. Bowen (1956), Boyer et.al. (2004) and Steward (2003).

5 Greenblatt, Stephen. Shakespearean Negotiations the Circulation of Social Energy in Renaissance England. The New Historicism: Studies in Cultural Poetics. Berkeley, California: University of California Press, 1988 
of society participated in the formation of the conceptual language of the early modern Western world and laid the foundation for modern society and legal thought. Representation of distinct the social spaces, with their own sets of ritual language and social, is mirrored in the often parodic use of hierarchical roles on the theatre stage, examples of this may be seen in several of the corrupt characters such as cardinals, nobles, judges and politicians. ${ }^{6}$

As the linguistic development of the use of conceptual metaphors reflected the rapid changes in a growing modern society, the creation of a modern legal system and a professional political system redefined the social language and the social landscape. ${ }^{7}$ The origin of an increasing explicit use of legal terminology in plays after the turn of the fifteenth century can be traced to the Inns of Court. ${ }^{8}$ This was the centre for legal education in England. The environment of didactic roleplaying here gave the students at the Inns the rhetorical and linguistic foundation needed to be a vital part of the development of a new political system centred on the idea of professionalism.?

In The Phoenix, the literary and philosophic heritage of the Arthurian myth found in Thomas Malory and Edmund Spenser is clearly evident, which I will return to in a moment. ${ }^{10}$ So also is the influence from the legal theorists and philosophers such as Henri de Bracton, Thomas Plowden and Edward Coke ${ }^{11}$ also prompted the development of new conceptual domains, from which concepts of legal principles blended with the development of metaphoric language. Here, a blending of the social spaces of established rituals emerge and construct a new mental space of social criticism. In the Duel Scene, (Scene 9, 99-277 (II.iii), the blended social spaces are both the factual and conceptual domains of the theatre, a tavern and a court trial to form a space with the possibility of commenting and criticising the legal and political development of Jacobean society. The representation of legal and socio-political discourses in Early Modern society of law and theatre, and of language and culture in society may be seen in the interpretation and application of languages both on stage, and in the court room. By looking at the blending of spaces in the realm of performance, both law and drama are constructed on

$6 \quad$ See Vinje, Wittgenstein, Whorf and Webster: Cognitive Metaphor Theory and Webster's legal drama, forthcoming, for a further discussion of the role and conceptual structure of Cardinal Monticelso in John Webster's The Duchess of Malfi.

$7 \quad$ The examples of this are manifold, one of the most influential was the spy network operated by Burleigh and Walsingham, cf. Budansky (2006), and Haynes (2000).

8 For a closer study of the Inns of Court and the importance of these to the arts, see Axton (1977), Prest (1986) and Hutson (2007).

9 Cf. Prest (1972)

10 Cf. Malory (1971), Spenser (2001)

11 Cf. Bracton (1968), Plowden (1659), and Coke (1628) 
the foundation of interpretation and ritual-based languages. Seen in light of the theatre, different types of languages, either metaphoric or performative, could be said to form variable types of blended spaces, both of narrative and characters, with an interpretative function. In the use of metaphors and languages seen in the court room and on stage, these engage in a mutual exchange of readings and interpretation, thus creating types of mental constructs and a mental framework in terms of contextual space.

The same point also holds in the way both common and scholarly interpretation take place in an environment that is more or less constructed upon ritual-based and socially constricted categories. With the interaction of several social discourses the exchange of social roles and rites combines with readings of languages commonly identified as restricted to one particular group of people and/ or settings, one might then transpose these to another medium or arena. This spatial and social blending combines the conceptual domains and contextual frames of these languages to create another type of social blended space of metaphor and criticism. This would, then, incorporate some of the functions of the source, with additional intended and unintended functions.

\section{The Phoenix: Legal Duel: Scene 9, 99-277 (II.iii)}

In the Duel Scene, legal language and legal commentary are explored by several means of conceptual constructions. The basis of this theoretical approach comes from the recent developments in cognitive metaphor theory. Some of the most influential figures come from the combined field of humanities and cognitive linguistics studies. ${ }^{12}$ The theatricality of law and the law trial is here seen together with several layers of factual and metaphoric spaces; so that metaphoric structures of legal arguments become vehicles for tenors of war and strife. Two common conceptual metaphors in legal discourse are: Legal Trial is War and Argument IS WAR. ${ }^{13}$ Both springs from the concept Argument, and in turn suggests the metaphoric structure and concept Argument As Duel, as opposed to the also very familiar conceptual metaphor Argument is a Journey. In the Duel Scene, it may be argued, there is a theatricalisation of a kind of metaphoric double duel, the first in which the two lawyers play out their legal arguments in order to defeat the other with juridical writs; the second in the actual sword fight they engage in at the same time. Both of these duels fit in with a larger overall metaphoric conceptual image of LAWYERS AS WARriors, though I will try to show how Middleton turns this into a much stronger social comment.

The scene is set in a tavern and feature justice of the peace Falso and the older litigator Tangle. In this first meeting with Tangle, Phoenix describes him

12 Cf. Lakoff (2008), Lakoff and Johnson (2003), Lakoff and Turner (1989), Lakoff (1987), Hogan (2003).

13 Lakoff and Johnson p. 4ff (2003) 
as "some old, busy, turbulent fellow: villainous law-worm, that eats holes into poor men's causes" (II.iv.43-45).

This particular sequence opens in a tavern after a discussion between Falso, his servant Latronello and Falso's niece. With the old Tangle approaching his former tutor, Latronello describes Tangle to Falso as an "old fellow, a kind of law-driver". This description of the lawyer as a "driver of the law" parallels with Middleton's friend and fellow playwright John Webster's later description of Duke Ferdinand in The Duchess of Malfi, in which Antonio describes him to Delio:

He speakes with others Tongues, and heares mens suites

With others Eares: will seeme to sleepe o'th' bench

Onely to intrap offenders in their answers;

Doomes men to death by information,

Rewards by heare-say.

To which Delio adds the comment "Then Law to him | Is like a fowle blacke cob-web to a Spider, | He makes it his dwelling, and a prison | To entangle those shall feede him." (DM. I.i.161-168). From this description and comment one could interpret the connection to a manipulating figure of corruptive power, and a figure who, as like a spider, controls the web of law. It should not be too difficult to see a similarity with Middleton's law-driver here.

After the description of Tangle, Falso approaches his old master and urges for a friendly duel, and exclaims:

My old master of fence: come, come, come, I have not exercised this twelve moons; I have almost forgot all my law-weapons. (114-116)

Immediately the use of 'law-weapons' sets the tone for the upcoming duel. The metaphoric use of weapons denotes specific legal writs, such as "longsword", which by Tangle is explained as "writ of delay." Scandala magnatum, insulting words spoken about a peer or other great person of the realm, is "backsword"14: "Scandals are backswords, indeed." says Falso. The performative aspect of this scene is also interesting as the stage directions states: "Enter Latronello with rapier and dagger foils", which would suggest that this scene is not only a duel of words, but a genuine duel. This image of two lawyers dueling both with words and swords suggests the fierceness of contemporary lawyers, and the attitude of the law courts. This is also discussed in a dialogue with the protagonist Phoenix, when Tangle compares himself with the Captain of the Guard by stating that "A man of war? A man of

$14 \quad$ OED.: 1. A sword with only one cutting edge. Also used by Visct. Bollingbroke in 1748: "The Back-Sword of Justice, which cuts only on one side." 
Thomas Middleton's Legal Duel: A Cognitive Approach

law is fit for a man of war; we both have no leisure to say prayers; we both kill o' Sunday mornings." (IV.194-195) The physical space in which they conduct their argument and duel is at an inn which contributes to the image of law and justice as degenerated.

The most salient concept in legal argumentation and discourse here is their relationship to war and duels. The most familiar in connection to the concepts legal discourse and argument are: Legal Trial is War and Argument is War which, in addition, provides the metaphoric structure and conceptual metaphor ARGUMENT AS DuEI, as opposed to the more familiar in academic circles of ARGUMENT AS JouRNEY. The journey here most often signify an inner journey towards a goal of knowledge, this conceptual metaphor suggests a more peaceful nature, one might argue that this could reflect a change in attitude to violence in Europe over the past 500 years, though, as I will point out later, the journey might also allude to medieval morality. The conceptual metaphor TRIAL AS WAR is in this comment somewhat altered into a much more insidious nature.

As the trial becomes an armed conflict and war, the lawyers would be perceived as the conceptual metaphor LAWYERS ARE WARRIORS. As I will argue later, this representation could be interpreted from a socio-historical viewpoint and function as an idolised picture of the KNIGHT OF JUSTICE. Though the nature of the duel and the LAWYERS ARE Assassins, but with the more sinister character description of the the conceptual metaphor Lawyers are Mercenaries. ${ }^{15}$ This latter, also functions as a comment on the corruptness of the legal branch and lawyers taking money for their services, pointing back to both Phoenix's description of Tangle and Latronello's. With this new blending of metaphoric concepts, the following conceptual pairs would emerge:

\section{Argument is armed Conflict and Argument is War Lawyers are Assassins and Lawyers are Mercenaries}

This small excerpt incorporates several layers of metaphoric concepts and theatrical representation of legal culture and social criticism. With the conceptual categories presented here a comment can be made on the use of the double duel concept as social criticism pointed towards the changes seen in behaviour of lawyers who are more interested in the battle and in money than in the purity and the honour of law.

15 This family resemblance of categories is seen as a generalized cognitive-social structure latent in the semantic field of the constructions, which warrants such a novel extension of the metaphors. In Lakoff's Women, Fire and Dangerous Thing (1987) the idea of Frame, or Idealised Cognitive Models (ICM), is describes as a prototype, and as the mental space in which we organise the categories and mental representations of what might be termed "meaning". In order not to stray too far from the main argument of this paper, I will not venture further into this theoretical discussion here, but rather devote more attention to it at a later stage. See also Vinje, The Legal Thought: A Cognitive metaphor approach to John Webster and Thomas Middleton's Legal Drama, (forthcoming). 


\section{Middleton and Arthurian Law}

Another aspect of this legal duel is Tangle's reminiscence of a now lost, but Arthurian Golden Age. The knightly era of the mythic King Arthur and his knights was familiar to Middleton not only through Geoffrey of Monmouth and Malory, but also through the more contemporary Edmund Spenser's The Faerie Queene. ${ }^{16}$ This knightly era, with purity of soul and purity of law, is pictured as an Arthurian time of chivalry; the purity and divine law of Arthur's court. The historical kingship of Henry III, and the laws of the medieval legal commentary Henry de Bracton give both a philosophical and a moral stand to the legal order of society. This was law that was both divine and above the faults of man; Bracton comments on the place of king and law, that "The law makes the king ... there is no king where will rules and not the law"17 as a monument to the moral imperative of justice. The stress on law in the middle ages was not only a moral imperative (as stressed by philosophers and the church), but also a means for the nobility to protect their privileges and curb the power of the king. As such, the moral aspects of the law were not only driving forces for change, but also post-hoc justifications for real politics.

Returning to the Duel Scene, in the middle of the duel Falso intends to apply yet another legal weapon, but petitions Tangle about it: "Thou art come to our present weapon, but what | call you sword and buckler, then?" Tangle, then, in a rather comical manner, intercuts the duel and goes into a lengthy comment on the now antiquated weapon:

O, that's out of use now! Sword and Buckler was called a good conscience, but that weapon's left long ago: that was too manly a fight, too sound a weapon for these our days. 'Slid, we are scarce able to lift up a buckler now, our arms are so bound to the pox; one good bang upon a buckler would make most of our gentlemen fly a'pieces: 'tis not for these linty times: our lawyers are good rapier and dagger men; they'll quickly despatch your -money. (II.iii.180188)

To which Falso replies "Indeed, since sword and buckler time, I have observed, there has been nothing so much fighting. Where be all our gallant swaggers? There are no good frays o'late." The social comment this description offers is a very poignant one, and contributes to the growing distrust in the legal and political system.

$16 \quad$ Monmouth (1966), Malory (2008), Spenser (2006).

17 Volume 2, page 110. 
Within the frame of purity of character a reference can be made in his description of the Spenserian Knight of the Red Crosse, and in extension, the Arthurian Jesuslike Knight Galahad. In Spenser's The Faerie Queene, this Gentle Knight is described as "Ycladd in mightie armes and siluer shielde" (Spenser: 2007, Book 1. Li). Middleton's familiarity with Spencer is clearly evident in his political play $A$ Game at Chess (1623), and in his civic pageant The Triumph of Truth (1613). Here the Spenser's monster Errour from Canto I of The Faerie Queene, 'Error' in Middleton, appears at the feet of the Machiavellian figuration of the Jesuit Ignatius Loyola, complete with "all symbols of the blind ignorance and darkness, [and with] mists hanging at his eyes" (O’Callaghan, 2009, 167).

In the footnote to this first stanza, the "mightie armes" are identified as "the armour of a Christian man specified by Saint Paul" and the "silver shielde' with the red cross as 'the shield of faith' an is also linked to St. George's shield (Spenser et al., 2007, 31n). The reference is to Galahad, whose shield once used to belong to Josephus, son of Joseph of Arimathea. It was a silver shield with a cross painted in "never-fading blood". ${ }^{18}$ The religious motif here is clearly present, and offers another level to Middleton's legal and social critique. But it also offers a more conceptual metaphor of the KNIGHT OF JusTICE and the idea of a protective knight or paladin of chivalry.

Also, in the widespread and widely read $O n$ the Laws and Governance of England by John Fortescue, Fortescue in the character of the Chancellor urges the young prince Edward of Wales to study the law, which is closely connected with the chivalry seen in Spenser. Here, the Chancellor argues for the law as a weapon since "as battles are determined by arms, so judgments are by laws" (Fortescue, 1997, 4). Further, the Chancellor quotes the epitome of justice, Emperor Justinian: "Imperial Majesty ought to be not only adorned with arms but also armed with laws, so that it can govern aright in both times of peace and of war" (4).

The Jacobean Lord chief justice Edward Coke (1552-1634) professed in his Comments on the Laws of England the importance of law over the function of the monarch, and also that law is governed by reason, Coke says «Reason is the life of the law,»:

nay, the common law itself is nothing else but reason; which is to be understood of as an artificial perfection of reason, gotten by long study. (Lewis, 2004, 108)

Coke's emphasis on reson and the law also extends to the order of law above individuals, even kings, he adds that 
No man (out of his own private reason) ought to be wiser than the law, which is the perfection of reason. (115)

It is from this approach to the idea of a perfect law and justice seen in Bracton and Coke, together with Aquinas' moral understanding and obligation towards the law Middleton turns when trying to show how far from this the representatives of the legal branch has fallen. In Aquinas's moral stand, this was something men had a moral obligation to obey out of a concern for the common good, as opposed to Coke's approach where Reason should govern men's obligation to follow the law.

Middleton's approach to law and the aggressive nature of it is paired with the corruptness of the institutions of Jacobean society. Thus we can see the conceptual categories Legal Trial is War and Argument as Duel, which in turn gives ARGUMENT AS WAR, as opposed to the category which was more likely to exist in an academic play, namely, ARGUMENT Is JourNEY.

These concepts are formed from the concepts Argument, Trial, and the basic conceptual metaphor of LIFE IS A JouRNEY. It is this concept of journey which is most predominant throughout the morality plays. Predominantly in medieval plays this particular scheme is found, Peter Happé identifies this structure as "Fall and Salvation of the sinner" and is the most common of all of these journey-based structures. The typical journey of the morality plays takes its eponymous Everyman hero from innocence, through a journey of temptation and fall, to repentance and redemption. ${ }^{19}$

Returning to the conceptual metaphor ARGUMENT AS JOURNEY, I would argue, can be compared to and contrasted with the Arthurian Quest motif of the Holy Grail. This was familiar to Middleton and his contemporaries from writers such as Thomas Malory and Spenser and their adaptations of Arthurian stories. A pairing of the quest motif with argument and the legal court provides a combination of the ancient religious and philosophical view on an idealised society and the perception of a reality modern corrupt society. The struggle for modern laws and a modern legal system opens up for a society in which justice can be bought and a pursuit of justice may be a quest into the bleak and corrupt society seen later in Webster.

This new conceptual category can then be read as TRIAL AS QUEST. The allegorical complexity of this motif can, thus, combine the quest for a moral purity in law, but also point out the futility of a search for morality in law. This is in stark contrast to medieval understanding of the nature of law. When read together with Bracton, Fortescue, Spenser and Coke, Tangle's description of 'conscience' could be read as a social comment on the negative development of the legal system, thus giving the Idealised Cognitive Models and opposition pair:

Ancient is Pure 
Thomas Middleton's Legal Duel: A Cognitive Approach

- Present is Corrupt

With the references to an idealised legal society, Middleton criticises the negative development of legal matters by directly comparing the contemporary situation to an idolised medieval era of knightly lawyers and morally pure of hearts judges.

From the structures and mental socio-cultural spaces seen in this scene, I would argue, that the following conceptual metaphors form family pairs of categories can be formed. These pairs work together to form a literary representation and an understanding of the way Middleton's legal London.

- Argument as War and Trial as Duel

- Argument as Journey and Trial as Journey

- Argument as Quest and Trial as Quest

The metaphorical language and the conceptual blended domains of tavern and law court in this scene, I would further argue, thus, paint a picture of the law as aggressive and corrupt. By looking at the source domains for the blended metaphors and conceptual structures in this scene, the social comment can become more visible and open up new ways of approaching this socio-political discourse. When compared to the later Elizabethan and Stuart political and legal plays, the salvation ending is twisted, and the fall of society has reached all of the spaces. With metaphorical constructs this change in tone is more evident in the later parts of the English Renaissance. At the end of most Elizabethan tragedies order is most often restored, but with many of the later Jacobean tragedies, Webster being perhaps the most vivid example of a system in chaos and juridical crisis, order is not restored. The corrupted system is not easily remedied.

\section{Conclusion}

The social, political, religious and legal changes in Tudor and Stuart England, surface not only in the social spaces of these discourses, but also with the university and Inns of Court wits, and the changes in conceptual metaphorical categories of blended spaces. By being directly involved in these changes and in these social spaces, social criticism grew along with the development of conceptual language. As seen in the scene from The Phoenix, plays and poetry developed alongside the societal changes, forming, not only the poetical language, but also the language and the concept of politics and law.

Conceptual language and development of social constructs throughout the English Renaissance, together with the long history of a commentary language on law from Bracton to Coke, embraced the formation of new social frames, not only of functions, but also of mind. The way in which Middleton approached and 
pursued a way of directly challenging and representing justice and theatricality carried with it a way of constructing conceptual blending across the social domains of law and artifice.

A central tenet of cognitive linguistics is that language is influenced by culture. Middleton's duel scene displays by the means of either conceptual metaphors or the blending of social spaces the corruptness of the Jacobean era. Jonathan Dollimore said about this that "the corrupt court is, of course, a recurrent setting for the drama; far from being (as is sometimes suggested) a transhistorical symbol of human depravity, this setting is and historically specific focus for a contemporary critique of power relations." (Dollimore: 2004, p. 4)

I would end with a postulation that the linguistic-cultural interaction between law and drama in this specific period had an enormous impact on both society and the development of theatrical practice and language. The way in which language is influenced, and in turn influences our conception of the reality that surrounds us, forms the way we construct reality and represent the law on stage.

John-Wilhelm Vinje

University of Agder

\section{References}

Axton, M., The Queen's two bodies: drama and the Elizabethan succession, London: Royal Historical Society, 1977.

Bracton, Henry de, and George E. Woodbine. Bracton on the Laws and Customs of England. Cambridge, Mass.: Harvard University Press, 1968.

Coke, E. and T. Littleton, Institutes of the laws of England, London: Printed by Adam Islip] for the Societie of Stationers, 1628.

Dollimore, Jonathan. Radical Tragedy Religion, Ideology, and Power in the Drama of Shakespeare and His Contemporaries. Durham: Duke University Press, 2004.

Fortescue, J. S., On the laws and governance of England, Cambridge: Cambridge University Press, 1997.

Greenblatt, Stephen. Shakespearean Negotiations the Circulation of Social Energy in Renaissance England. The New Historicism: Studies in Cultural Poetics. Berkeley, California:

University of California Press, 1988

Happé, P., English drama before Shakespeare, London: Longman, 1999.

Hogan, Patrick Colm, Cognitive Science, Literature, and the Arts : A Guide for Humanists,

New York ; London: Routledge, 2003

Hutson, L., The invention of suspicion: law and mimesis in Shakespeare and Renaissance drama. Oxford; New York: Oxford University Press, 2007.

Lakoff, G., The neural theory of metaphor. , The Cambridge handbook of metaphor and thought, 
Thomas Middleton's Legal Duel: A Cognitive Approach

R. W. J. Gibbs (Ed.) Cambridge: Cambridge University Press, 2008.

Lakoff, G., Women, fire, and dangerous things: what categories reveal about the mind, Chicago: University of Chicago Press, 1987.

Lakoff, G. and M. Johnson, Metaphors we live by, Chicago, Ill. London:University of Chicago Press, 2003.

Lakoff, G. and M. Turner, More than cool reason: a field guide to poetic metaphor, Chicago: University of Chicago Press, 1989.

Lacy, Norris J. Lancelot-Grail : The Old French Arthurian Vulgate and Post-Vulgate in Translation. 10 vols. Cambridge: D.S. Brewer, 2010.

Lewis, J. U., "His Theory of "Artificial Reason" as a Context for Modern Basic

Legal Theory", Law, Liberty, and Parliament: Selected Essays on the Writings of

Sir Edward Coke, Liberty Fund. ed. Allen D. Boyer, 2004.

Malory, Thomas. Le Morte Darthur: The Winchester Manuscript, Oxford, 2008.

Matarasso, Pauline Maud (ed.). The Quest of the Holy Grail. Penguin Classics. Baltimore,: Penguin Books, 1970.

Middleton, T. Thomas Middleton: The Collected Works. The Oxford Middleton. Oxford, Clarendon Press. Taylor, Gary et.al. eds. 2007.

O’Callaghan, M. Thomas Middleton, Renaissance dramatist, Edinburgh: Edinburgh University Press, 2009.

Plowden, Edmund. Commentaries, Trans. Hicks, Fabian. London: Printed by J.

Streater for Henry Twiford, 1659.

Prest, W. R., Inns of court under Elizabeth I and the early Stuarts, 1590-1640, Longman, 1972

Prest, W. R., The rise of the barristers: a social history of the English bar, 1590-1640.

Oxford, Oxford University Press, 1986.

Spenser, E., The Faerie Qveene, Ed. A. C. Hamilton, H. Yamashita, and T.

Suzuki(Rev 2nd ed. ed.). Harlow: Pearson Longman, 2007.

Vinje, John, The Legal Thought: A Cognitive metaphor approach to John Webster and Thomas Middleton's Legal Drama, forthcoming.

Vinje, John, Wittgenstein, Whorf and Webster: Cognitive Metaphor Theory and Webster's legal drama, forthcoming.

Webster, J. The Works of John Webster. Cambridge: Cambridge University Press. David Gunby et. al. eds. 1995-2007

Whorf, Benjamin Lee, and John Bissell Carroll. Language, Thought, and Reality. Selected Writings of B. L. Whorf. Ed.John B. Carroll. Technology Press of Massachusetts Institute of Technology; John Wiley \& Sons: New York; Chapman \& Hall: London, 1956. 